Check for updates

Cite this: RSC Adv., 2017, 7, 28702

\title{
Novel protostane-type triterpenoids with inhibitory human carboxylesterase 2 activities $\dagger$
}

\author{
Zhi-Jie Zhang, $\dot{t}^{\mathrm{a}}$ Xiao-Kui Huo, $\dot{t}^{\mathrm{b}}$ Xiang-Ge Tian, $\dot{t}^{\mathrm{c}}$ Lei Feng, ${ }^{\mathrm{b}}$ Jing Ning, ${ }^{\mathrm{b}}$ \\ Xin-Yu Zhao, ${ }^{b}$ Cheng-Peng Sun, (D)*b Chao Wang, ${ }^{\mathrm{b}}$ Sa Deng, ${ }^{\mathrm{b}}$ Bao-Jing Zhang, ${ }^{\mathrm{b}}$ \\ Hou-Li Zhang ${ }^{b}$ and Yong Liu*a
}

The rhizomes of Alisma orientalis have been used for centuries in China and other Asian countries as an effective herbal remedy. The phytochemical investigation of $A$. orientalis and biotransformation of two major triterpenoids alisols A (11) and B 23-acetate (13) by Cunninghamella elagans AS 3.2028 and Penicillium janthinellum AS 3.510 have led to the isolation of ten new protostane-type triterpenoids (1-5 and 18-22), including one novel 26-nor-protostane (1) and one unusual 17-nor-protostane (2), together with twelve known analogues. Their structures were determined by $1 D$ and 2D NMR, and HRESIMS spectroscopic analyses. All the isolated compounds were assayed for their inhibitory activities against human carboxylesterase 2 (HCE-2). Compounds 1, 3-9, 12, 14-16, 19, and 20 showed significant inhibitory activities on $\mathrm{HCE}-2$ with $\mathrm{IC}_{50}$ values from $0.51 \pm 0.09 \mu \mathrm{M}$ to $9.45 \pm 0.73 \mu \mathrm{M}$. The inhibition kinetics of compound 5 toward HCE-2 were established, and its $K_{\mathrm{i}}$ value was determined as $0.57 \mu \mathrm{M}$. The interaction of compound 5 with HCE-2 was investigated using molecular docking.

Received 30th April 2017 Accepted 25th May 2017 DOI: $10.1039 / c 7 r a 04841 f$ rsc.li/rsc-advances to play vital roles in drug metabolism and insecticide detoxication..$^{15}$ HCE-1 is abundantly expressed in the liver, whereas HCE-2 is predominately expressed in the gastrointestinal tract. HCE-2, as a major mediator, could reduce drug toxicity and enhance drug bioavailability in drug metabolism, thus, it has been paid more attention., ${ }^{3,14,16,17}$

As part of our ongoing research on the genus Alisma to discovery a series of potential inhibitors of HCE-2,,$^{3,14,18}$ the $80 \%$ EtOH extracts of rhizomes of A. orientalis were investigated to afford five new protostane-type triterpenoids (1-5), including two novel 26-nor and 17-nor protostanes (1 and 2) together with twelve known ones (6-17, Fig. 1). In order to enrich the chemical structures of protostane-type triterpenoids, two major constituents alisols A (11) and B 23-acetate (13) isolated from A. orientalis were biotransformed by Cunninghamella elagans AS 3.2028 and Penicillium janthinellum AS 3.510, respectively, to provide five new metabolites (18-22, Fig. 1). Their structures were determined by 1D and 2D NMR, and HRESIMS analyses. All these isolated compounds were evaluated for their inhibitory effects against HCE-2.

\section{Results and discussion}

Compound 1 has the molecular formula $\mathrm{C}_{29} \mathrm{H}_{44} \mathrm{O}_{3}$ by HRESIMS $\left(\mathrm{m} / z\right.$ 458.3631 $\left[\mathrm{M}+\mathrm{NH}_{4}\right]^{+}$, calcd for $\left.\mathrm{C}_{29} \mathrm{H}_{48} \mathrm{NO}_{3}, 458.3634\right)$ and ${ }^{13} \mathrm{C}$ NMR data, indicating 8 degrees of unsaturation. The ${ }^{1} \mathrm{H}$ NMR spectrum of 1 showed signals of two olefinic protons at $\delta_{\mathrm{H}}$ $6.77(1 \mathrm{H}, \mathrm{dt}, J=15.8,7.2 \mathrm{~Hz}, \mathrm{H}-23)$ and $6.00(1 \mathrm{H}, \mathrm{d}, J=15.8 \mathrm{~Hz}$, $\mathrm{H}-24)$ in combination with characteristic carbons at $\delta_{\mathrm{C}} 201.4$ (C- 


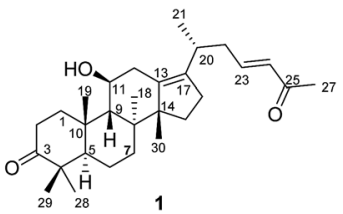

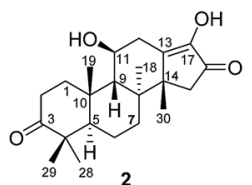

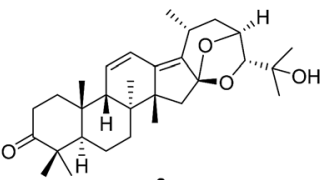

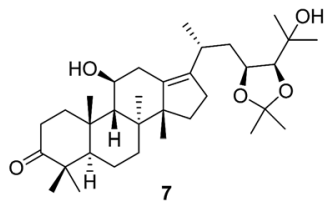

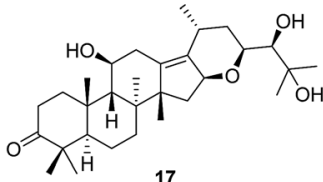
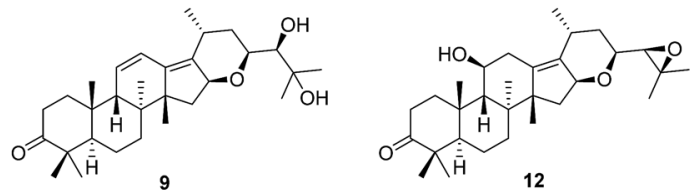

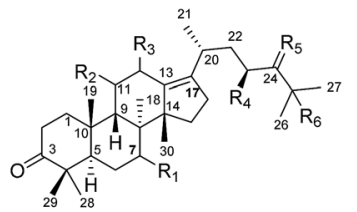

$5 \mathrm{R}_{1}=\mathrm{R}_{3}=\mathrm{H}, \mathrm{R}_{2}=\beta-\mathrm{OH}, \mathrm{R}_{4}=\mathrm{OH}, \mathrm{R}_{5}=\beta-\mathrm{OH}, \alpha-\mathrm{H}, \mathrm{R}_{6}=\mathrm{OBu}$ $10 R_{1}=R_{2}=R_{3}=H, R_{4}=R_{6}=O H, R_{5}=\beta O A c, \alpha-H$ $11 R_{1}=R_{3}=H_{1} R_{2}=\beta-O H, R_{4}=R_{6}=O H, R_{5}=\beta-O H, \alpha-H$ $14 \mathrm{R}_{1}=\mathrm{R}_{3}=\mathrm{H}_{1} \mathrm{R}_{2}=\beta-\mathrm{OH}, \mathrm{R}_{4}=\mathrm{OAc}, \mathrm{R}_{5}=\alpha-\mathrm{OH}, \beta-\mathrm{H}, \mathrm{R}_{6}=\mathrm{OH}$ $15 \mathrm{R}_{1}=\mathrm{R}_{3}=\mathrm{H}, \mathrm{R}_{2}=\beta-\mathrm{OH}, \mathrm{R}_{4}=\mathrm{R}_{6}=\mathrm{OH}, \mathrm{R}_{5}=\beta-\mathrm{OAc}, \alpha-\mathrm{H}$ $16 \mathrm{R}_{1}=\mathrm{R}_{3}=\mathrm{R}_{6}=\mathrm{H}, \mathrm{R}_{2}=\beta, \mathrm{OH}, \mathrm{R}_{4}=\mathrm{OAC}, \mathrm{R}_{5}=\mathrm{O}$ $18 \mathrm{R}_{1}=\alpha-\mathrm{OH}, \mathrm{R}_{2}=\beta-\mathrm{OH}, \mathrm{R}_{3}=\mathrm{H}, \mathrm{R}_{4}=\mathrm{R}_{6}=\mathrm{OH}, \mathrm{R}_{5}=\beta-\mathrm{OH}, \alpha-\mathrm{H}$ $19 \mathrm{R}_{1}=\mathrm{R}_{2}=\beta-\mathrm{OH}, \mathrm{R}_{3}=\mathrm{H}, \mathrm{R}_{4}=\mathrm{R}_{6}=\mathrm{OH}, \mathrm{R}_{5}=\beta-\mathrm{OH}, \alpha-\mathrm{H}$ $20 \mathrm{R}_{1}=\mathrm{R}_{3}=\alpha-\mathrm{OH}, \mathrm{R}_{2}=\beta-\mathrm{OH}, \mathrm{R}_{4}=\mathrm{R}_{6}=\mathrm{OH}, \mathrm{R}_{5}=\beta-\mathrm{OH}, \alpha-\mathrm{H}$ $21 \mathrm{R}_{1}=\mathrm{R}_{3}=\mathrm{H}, \mathrm{R}_{2}=\beta-\mathrm{OH}, \mathrm{R}_{4}=\mathrm{R}_{6}=\mathrm{OH}, \mathrm{R}_{5}=\mathrm{O}$ $22 \mathrm{R}_{1}=\mathrm{R}_{3}=\alpha-\mathrm{OH}, \mathbf{R}_{2}=\beta-\mathrm{OH}, \mathbf{R}_{4}=\mathbf{R}_{6}=\mathrm{OH}, \mathbf{R}_{5}=\mathrm{O}$

Fig. 1 Chemical constituents (1-17) of A. orientalis and biotransformed products (18-22) of alisols A (11) and B 23-acetate (13).
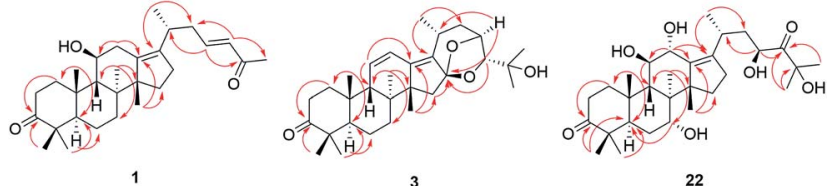

22

Fig. 2 Selected HMBC correlations of compounds 1, 3, and 22.

25), 150.2 (C-23), and 132.8 (C-24), indicating the presence of an $\alpha, \beta$-unsaturated carbonyl group. In the high field of ${ }^{1} \mathrm{H}$ NMR spectrum, the signals of seven methyl were observed at $\delta_{\mathrm{H}} 2.21$ (3H, s, Me-27), 1.13 (3H, s, Me-30), 1.07 (3H, s, Me-28), $1.06(3 \mathrm{H}$, d, $J=6.7 \mathrm{~Hz}, \mathrm{Me}-21), 1.04$ (3H, s, Me-19), 1.04 (3H, s, Me-29), and 1.04 (3H, s, Me-18). The ${ }^{13} \mathrm{C}$ NMR spectrum of 1 displayed 29 carbon resonances, including one carbonyl carbon $\left(\delta_{\mathrm{C}}\right.$ 223.7), two olefinic carbons $\left(\delta_{\mathrm{C}} 139.2\right.$ and 136.1), and an oxygenated carbon $\left(\delta_{\mathrm{C}} 70.5\right)$. All the above-mentioned data suggest that 1 was a nor-protostane type triterpenoid.,14,18 A comparison of ${ }^{1} \mathrm{H}$ and ${ }^{13} \mathrm{C}$ NMR data of 1 and alisol $\mathrm{A}(\mathbf{1 1})^{19}$ suggested that their difference was the side chain of C-17. The signals of three oxygenated carbons $\left[\delta_{\mathrm{C}} 77.6\right.$ (C-24), $74.1(\mathrm{C}-25)$, and 69.5 (C-23)] and one methyl carbon $\left[\delta_{\mathrm{C}} 27.6(\mathrm{C}-26)\right]$ in 11 were absent, and signals of one carbonyl carbon $\left[\delta_{\mathrm{C}} 201.4(\mathrm{C}\right.$ $25)]$ and two olefinic carbons $\left[\delta_{\mathrm{C}} 150.2\right.$ (C-23) and 132.8 (C$24)$ ] in 1 were present, which indicated the presence of a $\Delta^{23,24}$ double bond and a carbonyl group in the $\mathrm{C}-17$ side chain. The deduction was supported by an HMBC experiment in which showed correlations of Me- 2 with $\mathrm{C}-17 / \mathrm{C}-20, \mathrm{H}-23$ with $\mathrm{C}-20 / \mathrm{C}-$ 24/C-25, and Me-27 with C-24/C-25 (Fig. 2). The relative configuration of 1 was determined by NOESY correlations between $\mathrm{H}$ 11 and Me-18, requiring a $\beta$-orientation of $\mathrm{OH}-11$ (Fig. 3). The $\Delta^{23,24}$ double bond was deduced to be transformed on a basis of large coupling constants $\left[\delta_{\mathrm{H}} 6.77(1 \mathrm{H}, \mathrm{dt}, J=15.8,7.2 \mathrm{~Hz}, \mathrm{H}-23)\right.$ and $6.00(1 \mathrm{H}, \mathrm{d}, J=15.8 \mathrm{~Hz}, \mathrm{H}-24)]$. Thus, 1 was elucidated as alismanol $\mathrm{H}$.

Compound 2 was obtained as a white powder, and its molecular formula was defined as $\mathrm{C}_{22} \mathrm{H}_{32} \mathrm{O}_{4}$ based on HRESIMS $\left(\mathrm{m} / \mathrm{z} 383.2188[\mathrm{M}+\mathrm{Na}]^{+}\right.$, calcd for $\left.\mathrm{C}_{22} \mathrm{H}_{32} \mathrm{O}_{4} \mathrm{Na}, 383.2198\right)$ and ${ }^{13} \mathrm{C}$ NMR data. The ${ }^{1} \mathrm{H}$ NMR spectrum of 2 exhibited the presence of an oxygenated methine $\left[\delta_{\mathrm{H}} 3.98(1 \mathrm{H}, \mathrm{m}, \mathrm{H}-11)\right]$ and five methyls $\left[\delta_{\mathrm{H}} 1.33(3 \mathrm{H}, \mathrm{s}, \mathrm{Me}-30), 1.08(3 \mathrm{H}, \mathrm{s}, \mathrm{Me}-19), 1.08(3 \mathrm{H}, \mathrm{s}\right.$, Me-28), 1.05 (3H, s, Me-29), and 0.95 (3H, s, Me-30)]. The ${ }^{13} \mathrm{C}$ NMR spectrum of 2 revealed 22 carbons, including two carbonyl carbons $\left(\delta_{\mathrm{C}} 223.3\right.$ and 205.2), two olefinic carbons $\left(\delta_{\mathrm{C}} 152.4\right.$ and $148.3)$, and an oxygenated carbon $\left(\delta_{\mathrm{C}} 69.8\right)$. Compared with 20 -

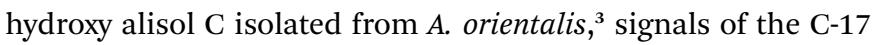
side chain in 20-hydroxyanisole $\mathrm{C}$ were absent, which suggested that 2 was a 17-nor protostane-type triterpenoid. In the HMBC spectrum of 2 , the correlations of $\mathrm{H}-12$ a with $\mathrm{C}-13, \mathrm{H}-13 \mathrm{~b}$ with $\mathrm{C}-13 / \mathrm{C}-14$, and $\mathrm{H}-15$ a with $\mathrm{C}-13 / \mathrm{C}-14 / \mathrm{C}-16$ confirmed the conclusion. The $\beta$-orientation of $\mathrm{OH}-11$ was determined by an NOESY correlation from $\mathrm{H}-11$ to Me-18. Thus, 2, as a first 17-nor protostane, was defined as alismanol I.

Compound 3, as a white powder, possessed a molecular formula of $\mathrm{C}_{30} \mathrm{H}_{44} \mathrm{O}_{4}$ established by HRESIMS $(\mathrm{m} / \mathrm{z} 469.3319$ [M $+\mathrm{H}]^{+}$, calcd for $\left.\mathrm{C}_{30} \mathrm{H}_{45} \mathrm{O}_{4}, 469.3318\right)$. The ${ }^{1} \mathrm{H}$ and ${ }^{13} \mathrm{C}$ NMR data of 3 were similar to those of 24-deacetyl alisol $\mathrm{O}(9)$ isolated from $A$. orientalis, ${ }^{20}$ except for chemical shifts of C-16 and C-24 deshielded from $\delta_{\mathrm{C}} 80.5$ and 76.3 in 9 to $\delta_{\mathrm{C}} 119.1$ and 86.2 in 3
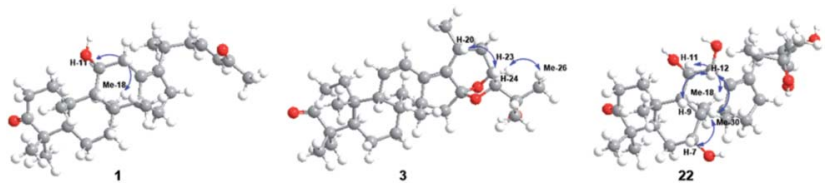

Fig. 3 Selected NOESY correlations of compounds 1, 3, and 22. 
and the absence of an oxygenated methine $\left[\delta_{\mathrm{H}} 4.57(1 \mathrm{H}, \mathrm{ddd}, J=\right.$ $7.9 \mathrm{~Hz}, \mathrm{H}-16)]$ in 9. The HMBC experiment of 3 displayed correlations of $\mathrm{H}-15 \mathrm{a} / \mathrm{H}-15 \mathrm{~b}$ with $\mathrm{C}-16, \mathrm{H}-24$ with $\mathrm{C}-16$, and $\mathrm{H}-23$ with $\mathrm{C}-16$ (Fig. 2), requiring the presence of a $\mathrm{C}(16)-\mathrm{O}-\mathrm{C}(23)$ unit and a C(16)-O-C(24) moiety. The relative configuration of 3 was established by NOESY correlations from $\mathrm{H}-20$ to $\mathrm{H}-24$ and $\mathrm{H}-23$ to Me-26 (Fig. 3), which indicated an $\alpha$-orientation of $\mathrm{H}-23$ and a $\beta$-orientation of $\mathrm{H}-24$. Accordingly, 3 was established as alismanol J.

Compound 4 was assigned the molecular formula $\mathrm{C}_{34} \mathrm{H}_{56} \mathrm{O}_{6}$ by HRESIMS $\left(m / z 581.3813[\mathrm{M}+\mathrm{Na}]^{+}\right.$, calcd for $\mathrm{C}_{34} \mathrm{H}_{54} \mathrm{O}_{6} \mathrm{Na}$, 581.3818) and ${ }^{13} \mathrm{C}$ NMR data. The ${ }^{1} \mathrm{H}$ and ${ }^{13} \mathrm{C}$ NMR data of 4 closely resembled those of alisol B 23-acetate (13), ${ }^{21}$ except for the presence of an ethoxy group $\left[\delta_{\mathrm{H}} 3.52\left(1 \mathrm{H}, \mathrm{m}, \mathrm{H}-1^{\prime} \mathrm{a}\right), 3.35\right.$ $\left(1 \mathrm{H}, \mathrm{m}, \mathrm{H}-1^{\prime} \mathrm{b}\right)$, and $1.16\left(3 \mathrm{H}, \mathrm{t}, J=7.0 \mathrm{~Hz}, \mathrm{Me}-2^{\prime}\right) ; \delta_{\mathrm{C}} 65.6\left(\mathrm{C}-1^{\prime}\right)$ and $\left.16.5\left(\mathrm{C}-2^{\prime}\right)\right]$ and an oxygenated methine $\left[\delta_{\mathrm{H}} 4.43(1 \mathrm{H}, \mathrm{dd}, J=\right.$ 8.0, 4.7 Hz, H-16)] in 4, and the downfield shifts of C-16 from $\delta_{\mathrm{C}}$ 29.1 in 13 to $\delta_{\mathrm{C}} 86.5$ in 4 , indicating the presence of an ethoxy moiety at C-16. The deduction was confirmed by HMBC correlations from $\mathrm{H}-1^{\prime} \mathrm{a} / \mathrm{H}-1^{\prime} \mathrm{b}$ to $\mathrm{C}-16 / \mathrm{C}-2^{\prime}$. In the NOESY spectrum of 4, cross-peaks of Me-18 with $\mathrm{H}-11 / \mathrm{H}-16$ suggested the $\beta$ configurations of OH-11 and OEt-16. In addition, the NOESY cross-peak from $\mathrm{H}-24$ to $\mathrm{Me}-27$ and the characteristic NMR data $\left[\delta_{\mathrm{H}} 4.74(1 \mathrm{H}, \mathrm{ddd}, J=10.6,8.5,2.0 \mathrm{~Hz}, \mathrm{H}-23)\right.$ and $2.73(1 \mathrm{H}, \mathrm{d}, J=$ $8.5 \mathrm{~Hz}, \mathrm{H}-24)$; $\delta_{\mathrm{C}} 73.7$ (C-23), 67.1 (C-24), and 60.5 (C-25)] suggested that 4 possessed the same side chain at $\mathrm{C}-17$ as alisol $\mathrm{B}$ series., ${ }^{3,18}$ Therefore, 4 was assigned as $16 \beta$-ethoxy alisol B 23acetate.

The molecular formula of 5 was established as $\mathrm{C}_{34} \mathrm{H}_{58} \mathrm{O}_{5}$ according to HRESIMS $\left(\mathrm{m} / z\right.$ 569.4181 $[\mathrm{M}+\mathrm{Na}]^{+}$, calcd for $\mathrm{C}_{34} \mathrm{H}_{56} \mathrm{O}_{5} \mathrm{Na}$, 569.4182) spectrum. Comparison of the ${ }^{1} \mathrm{H}$ and ${ }^{13} \mathrm{C}$ NMR data of 7 and alisol A (11) ${ }^{19}$ indicated the presence of a butyl group $\left[\delta_{\mathrm{H}} 3.41\left(2 \mathrm{H}, \mathrm{m}, \mathrm{H}_{2}-1^{\prime}\right), 1.49\left(2 \mathrm{H}, \mathrm{m}, \mathrm{H}_{2}-2^{\prime}\right), 1.37\right.$ $\left(2 \mathrm{H}, \mathrm{m}, \mathrm{H}_{2}-3^{\prime}\right)$, and $0.93\left(3 \mathrm{H}, \mathrm{t}, J=7.4 \mathrm{~Hz}, \mathrm{Me}-4^{\prime}\right) ; \delta_{\mathrm{C}} 62.3\left(\mathrm{C}-1^{\prime}\right)$, $33.9\left(\mathrm{C}-2^{\prime}\right), 20.7\left(\mathrm{C}-3^{\prime}\right)$, and $\left.14.5\left(\mathrm{C}-4^{\prime}\right)\right]$ in 5. The HMBC correlation from $\mathrm{H}-1^{\prime}$ to $\mathrm{C}-25$ and COSY cross-peaks of $\mathrm{H}-1^{\prime}$ with $\mathrm{H}-2^{\prime}$, $\mathrm{H}-2^{\prime}$ with $\mathrm{H}-3^{\prime}$, and $\mathrm{H}-3^{\prime}$ with $\mathrm{Me}-4^{\prime}$ suggested that the butyl moiety was attached to $\mathrm{OH}-25$. Thus, 5 was identified as 25-Obutyl alisol A.

HRESIMS spectrum of $\mathbf{1 8}$ showed a molecular ion peak at $\mathrm{m} /$ $z 529.3507[\mathrm{M}+\mathrm{Na}]^{+}$(calcd for $\mathrm{C}_{30} \mathrm{H}_{50} \mathrm{O}_{6} \mathrm{Na}, 529.3505$ ), which was the molecular formula $\mathrm{C}_{30} \mathrm{H}_{50} \mathrm{O}_{6}$. Compared with alisol $\mathrm{A}$ $(11),{ }^{19}$ the signal of an oxygenated methine $\left[\delta_{\mathrm{H}} 4.17(1 \mathrm{H}, \mathrm{dd}, J=\right.$ $6.4,1.1 \mathrm{~Hz}, \mathrm{H}-7)]$ was present, and the chemical shift value of $\mathrm{C}$ 7 was deshielded from $\delta_{\mathrm{C}} 34.6$ in 11 to $\delta_{\mathrm{C}} 67.9$ in 18. The above data required the location of a hydroxy group at $\mathrm{C}-7$, which was further confirmed by HMBC correlations of $\mathrm{H}-7$ with $\mathrm{C}-5 / \mathrm{C}-8 / \mathrm{C}-$ 14 and COSY correlations from $\mathrm{H}-5$ to $\mathrm{H}-6 \mathrm{a} / \mathrm{H}-6 \mathrm{~b}$ and $\mathrm{H}-6 \mathrm{a} / \mathrm{H}-6 \mathrm{~b}$ with H-7. The NOESY spectrum of 18 exhibited cross-peaks between $\mathrm{H}-7$ and $\mathrm{H}-9 / \mathrm{Me}-30$, indicating that $\mathrm{OH}-7$ was $\alpha-$ oriented. Thus, 18 was established as $7 \alpha$-hydroxy alisol A.

HRESIMS data of 19 suggested that 19 possessed the same molecular formula as 18. The ${ }^{1} \mathrm{H}$ and ${ }^{13} \mathrm{C}$ NMR spectroscopic data of 19 were similar to those of $\mathbf{1 8}$, with the exception that the signal of $\mathrm{H}-7$ was shielded from $\delta_{\mathrm{H}} 4.17(1 \mathrm{H}, \mathrm{dd}, J=6.4,1.1 \mathrm{~Hz})$ in 18 to $\delta_{\mathrm{H}} 3.75(1 \mathrm{H}, \mathrm{dd}, J=13.7,6.4 \mathrm{~Hz})$ in 19 , and the chemical shift of C-7 was deshielded from $\delta_{\mathrm{C}} 69.7$ in 18 to $\delta_{\mathrm{C}} 81.8$ in 19, which suggested that their difference was the configuration of C-7. The deduction was confirmed by an NOESY correlation of $\mathrm{H}-7$ with Me-18, indicating a $\beta$-orientation of $\mathrm{OH}-7$. Accordingly, 19 was defined as $7 \beta$-hydroxy alisol A.

HRESIMS spectrum of 20 observed a molecular ion peak at $m / z 527.3343[\mathrm{M}+\mathrm{Na}]^{+}$(calcd for $\mathrm{C}_{30} \mathrm{H}_{48} \mathrm{O}_{6} \mathrm{Na}, 527.3349$ ), which suggested that its molecular formula was $\mathrm{C}_{30} \mathrm{H}_{50} \mathrm{O}_{7}$. A comparison of NMR data of 20 and 18 revealed that the chemical shift value of C-12 was deshielded from $\delta_{\mathrm{C}} 35.1$ in 18 to $\delta_{\mathrm{C}} 67.6$ in 20, requiring the location of a hydroxy group at $\mathrm{C}-12$. In the HMBC spectrum of 20, the long-range correlations from $\mathrm{H}-9 / \mathrm{H}-11$ to $\mathrm{C}-$ 12 and $\mathrm{H}-12$ to $\mathrm{C}-9 / \mathrm{C}-11 / \mathrm{C}-13 / \mathrm{C}-17$ confirmed the deduction. The NOESY spectrum of 20 observed the cross-peaks of $\mathrm{H}-12$ with $\mathrm{H}-9 / \mathrm{Me}-19$, indicating an $\alpha$-orientation of $\mathrm{OH}-12$. Therefore, 20 was defined as $7 \alpha, 12 \alpha$-dihydroxy alisol A.

Compound 21 was obtained as a white powder. Its molecular formula was assigned as $\mathrm{C}_{30} \mathrm{H}_{50} \mathrm{O}_{7}$ established by HRESIMS $(\mathrm{m} / \mathrm{z}$ $545.3457[\mathrm{M}+\mathrm{Na}]^{+}$, calcd for $\left.\mathrm{C}_{30} \mathrm{H}_{50} \mathrm{O}_{7} \mathrm{Na}, 545.3454\right)$ data. The 1D NMR data indicated that $\mathbf{2 1}$ was a protostane-type triterpenoid with a C-3 carbonyl group,, ${ }^{3,14,18}$ a C-13/C-17 cyclic double bond, and oxygenated carbons (C-7, C-11, C-23, C-25), which suggested that the structure of 21 was similar to that of 19, except for C-24. The C-24 carbonyl moiety was established through an $\mathrm{HMBC}$ experiment in which showed long-range correlations of $\mathrm{H}-23$ with C-24/C-25 and Me-26/Me-27 with C$24 / \mathrm{C}-25$. The $\alpha$-orientation of $\mathrm{OH}-7$ was established by NOESY cross-peak of H-7 with Me-30. Therefore, 21 was defined as $7 \alpha-$ hydroxy-24-oxo alisol A.

Analysis of HRESIMS and 1D NMR data of 22 and 21 revealed that their differences were in ring $\mathrm{C}$ since signals of an oxygenated methine were observed at $\delta_{\mathrm{H}} 4.55(1 \mathrm{H}, \mathrm{d}, J=5.0 \mathrm{~Hz}$, $\mathrm{H}-12)$ and $\delta_{\mathrm{C}} 67.7$ (C-12). This conclusion was supported by HMBC correlations from $\mathrm{H}-9$ to $\mathrm{C}-12$ and $\mathrm{H}-12$ to $\mathrm{C}-9 / \mathrm{C}-11 / \mathrm{C}-13$ / C-17 (Fig. 2). The configurations of $\mathrm{OH}-7$ and $\mathrm{OH}-12$ were assigned as an $\alpha$-orientation based on the correlations of $\mathrm{H}-7$ with Me-30 and H-12 with H-9/Me-30 in the NOESY experiment (Fig. 3). Accordingly, 22 was established as $7 \alpha, 12 \alpha-$ dihydroxy-24-oxo alisol A.

In addition, eleven known compounds were isolated from the dried rhizomes of $A$. orientalis, and their structures were elucidated to be alisol C 23-acetate (6), ${ }^{19}$ alisol A 23,24-acetonide (7), ${ }^{5}$ 11-deoxy alisol B (8), ${ }^{19}$ 24-deacetyl alisol O (9), ${ }^{20}$ 11-deoxy alisol A (10), ${ }^{19}$ alisol A (11), ${ }^{19}$ 16,23-oxido alisol B (12), ${ }^{19}$ alisol B 23-acetate (13), ${ }^{21}$ alisol E 23-acetate (14), ${ }^{22}$ alisol A 24-acetate (15), ${ }^{19}$ alisol B monoacetate (16), ${ }^{23}$ and alisol F (17). ${ }^{22}$

Previous investigation of the biotransformation of protostane-type triterpenoid alisol G by P. janthinellum AS 3.510 led to four new metabolites, which demonstrated that microbial transformation is an important approach to rich structural diversity of protostane-type triterpenoids. ${ }^{14}$ In this work, the biotransformation of alisols A (11) and B 23-acetate (13) by $C$. elagans AS 3.2028 and P. janthinellum AS 3.510, respectively, yielded five new metabolites (18-22). According to the biotransformed results, C. elagans AS 3.2028 and P. janthinellum AS 3.510 possessed the hydroxylated and oxidized capabilities, while hydroxylation is still its main reaction, and their biotransformation sites could be at C-7 and C-12. 
In drug metabolism, HCE-2 plays an important role in reducing drug toxicity and enhancing drug bioavailability. ${ }^{\mathbf{3 , 1 4 , 1 6 , 1 7}}$ Previous studies have indicated that protostanetype triterpenoids possess inhibitory activities on HCE-2.,14 Therefore, all the isolated compounds were assayed for inhibitory HCE-2 effects. As shown in Table 4, compound 5 exerted the most significant inhibitory activities with $\mathrm{IC}_{50}$ of $0.51 \pm 0.09$ $\mu \mathrm{M}$, and others $1,3,4,6-9,12,14-16,19$, and 20 displayed significant inhibitory activities against HCE-2 with $\mathrm{IC}_{50}$ values from $2.58 \pm 0.51 \mu \mathrm{M}$ to $9.45 \pm 0.73 \mu \mathrm{M}$. A comparison of the inhibitory efficiency of 5, 11, and 15 indicated that acetyl and butyl groups linked at $\mathrm{OH}-24$ and $\mathrm{OH}-25$ were benefit for inhibitory activities. The biotransformed products (18-22) displayed more significant inhibitory effects than the substrates (11 and 13). Compound 18 showed moderate inhibitory effect with the $\mathrm{IC}_{50}$ value of $18.05 \pm 1.53 \mu \mathrm{M}$, whereas $\mathrm{IC}_{50}$ values of compounds 19 and 20 were $7.39 \pm 1.21$ and $3.73 \pm 0.76 \mu \mathrm{M}$, respectively, which suggested that the $\beta$-configuration of $\mathrm{OH}-7$ and the oxidization of $\mathrm{OH}-24$ were in favour of inhibition on HCE-2. The results indicated that biotransformation was an effective method to rich the structure of protostane-type triterpenoids and improve their bioactivities.

The inhibition kinetics and $K_{\mathrm{i}}$ value were further investigated (Fig. 4) in order to indicate the potential inhibition of HCE-2 by compound 5. As shown in Fig. 4, compound 5 displayed concentration-dependent inhibition of HCE-2, and the $K_{\mathrm{i}}$ value was calculated as $0.57 \mu \mathrm{M}$ for the activity of HCE-2.

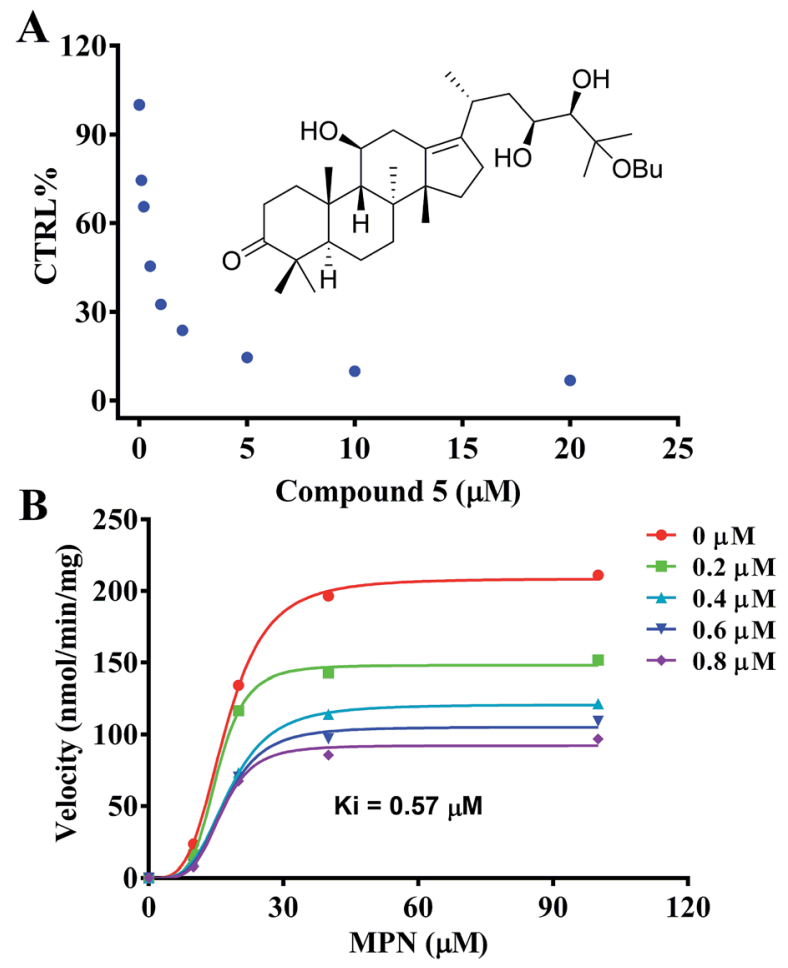

Fig. 4 Evaluation of the inhibition of recombinant HCE-2 by compound 5. (A) Compound 5 exhibited concentration-dependent inhibition of HCE-2. (B) The inhibition kinetics of compound 5.

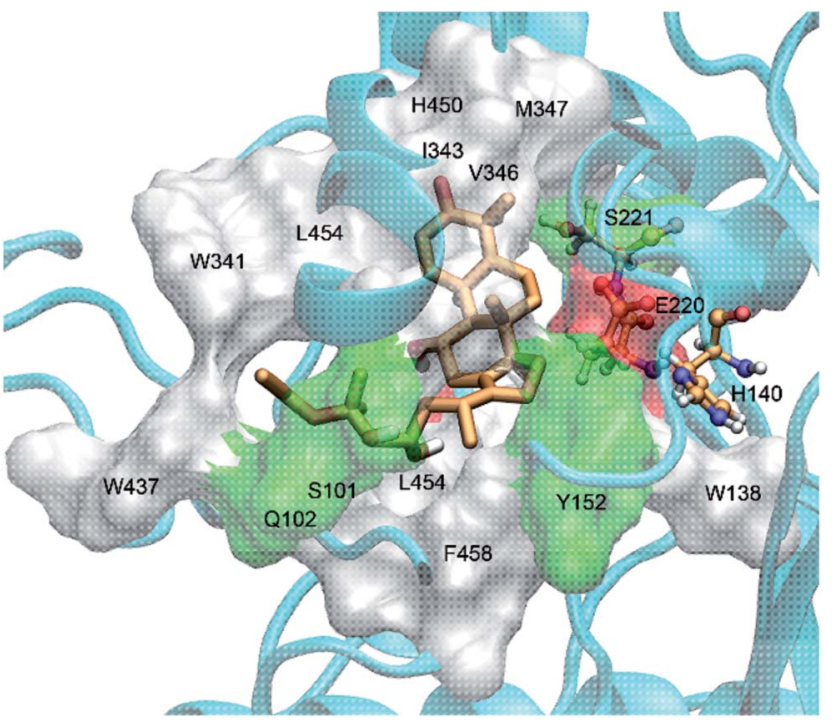

Fig. 5 Possible binding modes of the amino acid residues Ser-221, Glu-220, and His-140 in an active site triad of HCE-2 with compound 5. White, nonpolar amino acid; green, polar amino acid; red, acidic amino acid.

The interaction mechanism between compound 5 and HCE-2 was also investigated. As shown in Fig. 5, compound 5 could be well docked into the catalytic site of HCE-2, while the carbonyl group of compound 5 was near to the catalytic site of HCE-2 (Ser221, Glu-220, and His-140). As a result, the docking in the best binding mode gave rise to the lowest binding free energy $(-5.97$ kcal $\mathrm{mol}^{-1}$ ), indicating that compound 5 had high affinity for HCE-2, which was in agreement with our results.

\section{Conclusions}

Investigation on the rhizomes of $A$. orientalis led to the isolation and structure elucidation of five new triterpenoids including two novel nor-protostanes (1 and 2 ) as well as thirteen analogues. It was first reported about the presence of 17-nor protostane-type triterpenoid (2) in nature. In addition, two major constituents of A. orientalis, alisols A (11) and B 23-acetate (13) were transformed by C. elagans AS 3.2028 and P. janthinellum AS 3.510, respectively, yielding five new metabolites (18-22). The results indicated that $C$. elagans AS 3.2028 and P. janthinellum AS 3.510 mainly possessed the hydroxylated and oxidized activities in these biotransformation processes, and their hydroxylated sites could be at C-7 and C12. Compounds 1, 3-9, 12, 14-16, 19, and 20 showed significant inhibitory activities on HCE-2 with $\mathrm{IC}_{50}$ values from $0.51 \pm 0.09$ $\mu \mathrm{M}$ to $9.45 \pm 0.73 \mu \mathrm{M}$. The inhibition kinetics of compound 5 toward HCE-2 were established, and the $K_{\mathrm{i}}$ value was determined as $0.57 \mu \mathrm{M}$. The interaction of compound 5 with HCE-2 was validated using the molecular docking.

\section{Experimental section}

\section{General methods and materials}

Optical rotations were measured on a Perkin-Elmer 241 polarimeter. UV spectra were recorded on a JASCO V-650 
spectrophotometer. The NMR spectra were recorded on a Bruker600 spectrometer, using tetramethylsilane (TMS) as internal standard. Chemical shifts are in $\delta$ (ppm), and coupling constants $(J)$ in Hz. HRESIMS spectra were measured on an Agilent 1100 series LC/MSD ion trap mass spectrometer. High-performance liquid chromatography (HPLC) analyses were performed on a UItimate 3000 HPLC system equipped with a photodiode array detector and a quaternary pump system and a column compartment. Preparative HPLC was performed on an Elite P2300 instrument with an Elite UV2300 detector and a Thermo $\mathrm{C}_{18}$ column $(250 \mathrm{~mm} \times 10$ $\mathrm{mm}, 5 \mu \mathrm{m})$. All solvents were obtained from Tianjin Kemiou Chemical Reagent Company (Tianjing, China), $\mathrm{CH}_{3} \mathrm{CN}$ and $\mathrm{MeOH}$ for HPLC analysis were chromatographic grade (Merck, Darmstadt, Germany). Silica gel (200-300 mesh) for column chromatography (CC) were purchased from Qingdao Marine Chemical Factory (Qingdao, People's Republic of China).

\section{Plant material}

Dried rhizomes of $A$. orientalis were purchased in January 2013 from Beijing Tongrentang Co., Ltd., China, and identified by
Prof. Jing-Ming Jia, Shenyang Pharmaceutical University. A voucher specimen (301114120P) has been deposited in the herbarium of the Department of Medicinal Chemistry, Dalian Medical University.

\section{Extraction and isolation}

The dried rhizomes of $A$. orientalis ( $4.0 \mathrm{~kg}$ ) were extracted with $80 \%$ EtOH $(3 \times 2 \mathrm{~h} \times 10 \mathrm{~L})$ to afford a residue after solvent removal in vacuo. The residue was suspended in $\mathrm{H}_{2} \mathrm{O}(5 \mathrm{~L})$, and extracted with petroleum ether $(3 \times 5 \mathrm{~L}), \mathrm{CHCl}_{3}(3 \times 5 \mathrm{~L})$, EtOAc $(3 \times 5 \mathrm{~L})$, and $n-\mathrm{BuOH}(3 \times 5 \mathrm{~L})$, successively.

The $\mathrm{CHCl}_{3}$ extract $(240 \mathrm{~g})$ was separated by a silica gel column, eluted with $\mathrm{CHCl}_{3}-\mathrm{MeOH}(100: 1-4: 1)$, to afford fractions 1-24. Fr. 6 (7.8 g) was purified by an ODS column with $\mathrm{CH}_{3} \mathrm{CN}-\mathrm{H}_{2} \mathrm{O}(20-60 \%)$ and preparative HPLC $\left(\mathrm{CH}_{3} \mathrm{CN}-\mathrm{H}_{2} \mathrm{O}\right.$, $25 \%$ ) to obtain compounds 7 (9 mg) and 16 (3 mg).

The EtOAc extracts (43 g) were subjected to silica gel CC eluted with $\mathrm{CH}_{2} \mathrm{Cl}_{2}-\mathrm{MeOH}(100: 1-1: 1)$ to afford fractions 127. Fr. 7 (2.5 g) was separated by an ODS column eluted with $\mathrm{MeOH}-\mathrm{H}_{2} \mathrm{O}$ (50-80\%), and purified by preparative HPLC

Table $1{ }^{1} \mathrm{H}$ NMR data of compounds $1-5\left(600 \mathrm{MHz}, \mathrm{MeOH}-d_{4}, \delta_{\mathrm{H}}\right.$ in ppm, $\mathrm{J}$ in $\left.\mathrm{Hz}\right)$

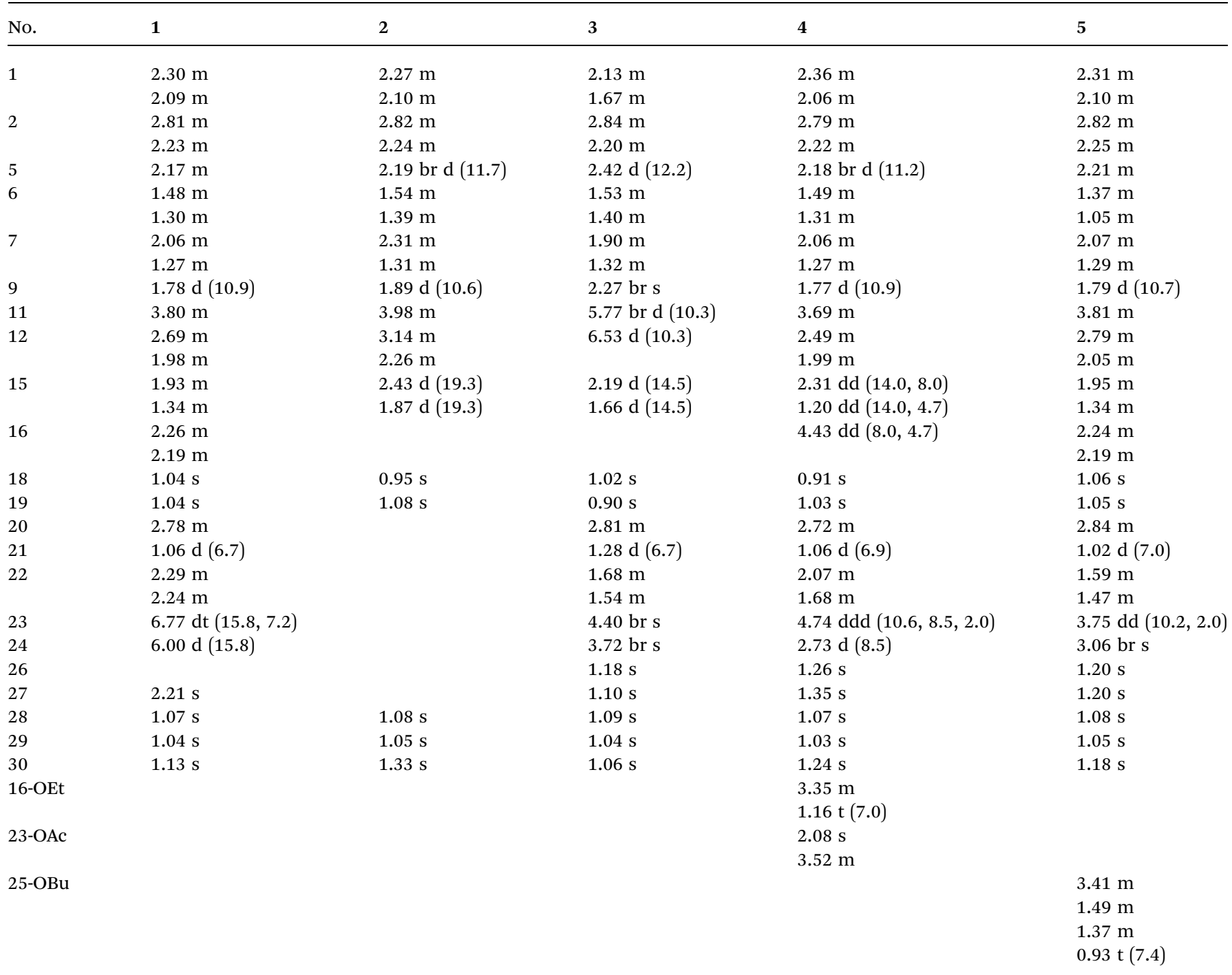


$\left(\mathrm{CH}_{3} \mathrm{CN}-\mathrm{H}_{2} \mathrm{O}, 40-60 \%\right)$ to afford compounds 1 (2 mg), 4 (22 $\mathrm{mg}$ ), 6 (2 mg), 11 (510 mg), 13 (450 mg), and 17 (9 mg). Fr. 9 (1.6 g) was separated through ODS CC eluted with $\mathrm{MeOH}-\mathrm{H}_{2} \mathrm{O}(60-$ $80 \%)$, and purified by preparative $\mathrm{HPLC}\left(\mathrm{CH}_{3} \mathrm{CN}-\mathrm{H}_{2} \mathrm{O}, 40-55 \%\right)$ to afford compounds 10 (2 mg), 14 (15 mg), and 15 (9 mg).

The $n$-BuOH extracts ( $86 \mathrm{~g}$ ) were subjected to D101 resin CC eluted with EtOH- $\mathrm{H}_{2} \mathrm{O}(0-95 \%)$ to afford four fractions 1-4. Fr. 4 (3.0 g) was separated by a silica gel column eluted with petroleum ether-acetone $(10: 1-1: 1)$, yielding four subfractions Fr. 41-Fr. 44. The purification of Fr. 44 (2.0 g) by HPLC eluted with $\mathrm{MeOH}-\mathrm{H}_{2} \mathrm{O}(75-85 \%)$ has led to the isolation of compounds 2 ( $2 \mathrm{mg}), 3$ (41 mg), 5 (1.9 mg), 8 (4 mg), 9 (2 mg), and 12 ( $3 \mathrm{mg})$.

Alismanol H (1). Amorphous powder; $[\alpha]_{\mathrm{D}}^{25} 96.0$ (c 0.2 , $\mathrm{MeOH}) ; \mathrm{UV}(\mathrm{MeOH}) \lambda_{\max }(\log \varepsilon) 222(4.0) \mathrm{nm} ;{ }^{1} \mathrm{H}(600 \mathrm{MHz}$, $\left.\mathrm{MeOH}-d_{4}\right)$ and ${ }^{13} \mathrm{C}$ NMR $\left(150 \mathrm{MHz}, \mathrm{MeOH}-d_{4}\right)$ data, see Tables 1 and 3; HRESIMS $m / z$ 458.3631 $\left[\mathrm{M}+\mathrm{NH}_{4}\right]^{+}$(calcd for $\mathrm{C}_{29} \mathrm{H}_{48} \mathrm{NO}_{3}$, 458.3634).

Alismanol I (2). Amorphous powder; $[\alpha]_{\mathrm{D}}^{25} 114.0$ (c 0.1, $\mathrm{MeOH}) ; \mathrm{UV}(\mathrm{MeOH}) \lambda_{\max }(\log \varepsilon) 267$ (3.9) nm; ${ }^{1} \mathrm{H}(600 \mathrm{MHz}$, $\left.\mathrm{MeOH}-d_{4}\right)$ and ${ }^{13} \mathrm{C}$ NMR $\left(150 \mathrm{Mz}, \mathrm{MeOH}-d_{4}\right)$ data, see Tables 1 and 3; HRESIMS $m / z$ 383.2188 $[\mathrm{M}+\mathrm{Na}]^{+}$(calcd for $\mathrm{C}_{22} \mathrm{H}_{32} \mathrm{O}_{4} \mathrm{Na}$, 383.2198).

Alismanol J (3). Amorphous powder; $[\alpha]_{\mathrm{D}}^{25}-20.0(c$ 0.125, $\mathrm{MeOH}) ; \mathrm{UV}(\mathrm{MeOH}) \lambda_{\max }(\log \varepsilon) 250(3.9) \mathrm{nm} ;{ }^{1} \mathrm{H}(600 \mathrm{MHz}$, $\left.\mathrm{MeOH}-d_{4}\right)$ and ${ }^{13} \mathrm{C}$ NMR $\left(150 \mathrm{MHz}, \mathrm{MeOH}-d_{4}\right)$ data, see Tables 1 and 3; HRESIMS $m / z 469.3319[\mathrm{M}+\mathrm{H}]^{+}$(calcd for $\mathrm{C}_{30} \mathrm{H}_{45} \mathrm{O}_{4}$, 469.3318).
16 $\beta$-Ethoxy alisol B 23-acetate (4). Amorphous powder; $[\alpha]_{\mathrm{D}}^{25} 60.0(c 0.1, \mathrm{MeOH}) ; \mathrm{UV}(\mathrm{MeOH}) \lambda_{\max }(\log \varepsilon) 203(4.0) \mathrm{nm} ;{ }^{1} \mathrm{H}$ $\left(600 \mathrm{MHz}, \mathrm{MeOH}-d_{4}\right)$ and ${ }^{13} \mathrm{C} \mathrm{NMR}\left(150 \mathrm{MHz}, \mathrm{MeOH}-d_{4}\right)$ data, see Tables 1 and 3; HRESIMS $m / z 581.3813[\mathrm{M}+\mathrm{Na}]^{+}$(calcd for $\mathrm{C}_{34} \mathrm{H}_{54} \mathrm{O}_{6} \mathrm{Na}$, 581.3818).

25-O-Butyl alisol A (5). Amorphous powder; $[\alpha]_{\mathrm{D}}^{25}-14.0$ (c 0.1, $\mathrm{MeOH}) ; \mathrm{UV}(\mathrm{MeOH}) \lambda_{\max }(\log \varepsilon) 202(3.9) \mathrm{nm} ;{ }^{1} \mathrm{H}(600 \mathrm{MHz}$, $\left.\mathrm{MeOH}-d_{4}\right)$ and ${ }^{13} \mathrm{C} \mathrm{NMR}\left(150 \mathrm{MHz}, \mathrm{MeOH}-d_{4}\right)$ data, see Tables 1 and 3; HRESIMS $m / z 569.4181[\mathrm{M}+\mathrm{Na}]^{+}$(calcd for $\mathrm{C}_{34} \mathrm{H}_{56} \mathrm{O}_{5} \mathrm{Na}$, 569.4182).

\section{Biotransformation of alisols A (11) and B 23-acetate (13)}

Aspergillus niger AS 3.739, A. niger AS 3.4627, A. niger AS 3.795, A. niger AS 3.1858, Chaetomium blakesleana AS 3.910, C. blakesleana AS 3.970, Cunninghamella elegans AS 3.1207, C. echinulata AS 3.2004, C. elegans AS 3.2028, C. echinulata AS 3.3400, Syncephalastrum racemosum AS 3.264, Fusarium avenaceum AS 3.4594, Penicillium melinii AS 3.4474, P. janthinellum AS 3.510, and Mucor rouxianus AS 3.3447 were purchased from Chinese General Microbiological Culture Collection Center in Beijing, China. All the culture and biotransformation experiments were performed as the previous method. ${ }^{24}$ Preliminary screenings were performed in $250 \mathrm{~mL}$ Erlenmeyer flasks containing potato medium $(100 \mathrm{~mL})$. After incubation for $24 \mathrm{~h}, 0.2 \mathrm{~mL}$ of alisols A (11) or B 23-acetate (13) $\left(10 \mathrm{mg} \mathrm{mL}^{-1}\right.$, in $\left.\mathrm{MeOH}\right)$ was added to each flask for preliminary screening and incubated for 3 days. Both substrate and organism controls were incubated under the

Table $2{ }^{1} \mathrm{H}$ NMR data of compounds $18-22\left(600 \mathrm{MHz}, \mathrm{MeOH}-d_{4}, \delta_{\mathrm{H}}\right.$ in ppm, $\mathrm{J}$ in $\mathrm{Hz}$ )

\begin{tabular}{|c|c|c|c|c|c|}
\hline No. & 18 & 19 & 20 & 21 & 22 \\
\hline \multirow[t]{2}{*}{1} & $2.26 \mathrm{~m}$ & $2.28 \mathrm{~m}$ & $2.30 \mathrm{~m}$ & $2.28 \mathrm{~m}$ & $2.30 \mathrm{~m}$ \\
\hline & $2.11 \mathrm{~m}$ & $2.19 \mathrm{~m}$ & $2.20 \mathrm{~m}$ & $2.19 \mathrm{~m}$ & $2.20 \mathrm{~m}$ \\
\hline \multirow[t]{2}{*}{2} & $2.81 \mathrm{~m}$ & $2.82 \mathrm{~m}$ & $2.82 \mathrm{~m}$ & $2.82 \mathrm{~m}$ & $2.82 \mathrm{~m}$ \\
\hline & $2.21 \mathrm{~m}$ & $2.22 \mathrm{~m}$ & $2.23 \mathrm{~m}$ & $2.22 \mathrm{~m}$ & $2.23 \mathrm{~m}$ \\
\hline 5 & $2.45 \mathrm{dd}(13.4,1.5)$ & $2.45 \mathrm{~m}$ & $2.42 \mathrm{dd}(13.0,1.5)$ & $2.45 \mathrm{~m}$ & $2.43 \mathrm{dd}(13.5,2.0)$ \\
\hline \multirow[t]{2}{*}{6} & $1.71 \mathrm{~m}$ & $1.71 \mathrm{~m}$ & $1.72 \mathrm{~m}$ & $1.72 \mathrm{~m}$ & $1.76 \mathrm{~m}$ \\
\hline & $1.38 \mathrm{~m}$ & $1.47 \mathrm{~m}$ & $1.39 \mathrm{~m}$ & $1.39 \mathrm{~m}$ & $1.40 \mathrm{~m}$ \\
\hline 7 & $4.17 \mathrm{dd}(6.4,1.1)$ & 3.75 dd $(13.7,6.4)$ & $4.23 \mathrm{br} \mathrm{d}(6.0)$ & $4.18 \mathrm{~d}(5.0)$ & $4.25 \mathrm{br} \mathrm{d}(5.5,1.5)$ \\
\hline 9 & $1.61 \mathrm{~d}(10.2)$ & $2.08 \mathrm{~d}(10.4)$ & $1.85 \mathrm{~d}(11.5)$ & $1.61 \mathrm{~d}(10.7)$ & $1.86 \mathrm{~d}(11.0)$ \\
\hline 11 & $3.86 \mathrm{~m}$ & $3.84 \mathrm{~m}$ & 3.91 dd $(11.0,4.5)$ & $3.87 \mathrm{~m}$ & $3.91 \mathrm{dd}(11.0,5.0)$ \\
\hline \multirow[t]{2}{*}{12} & $2.79 \mathrm{~m}$ & $2.79 \mathrm{~m}$ & $4.53 \mathrm{~d}(4.5)$ & $2.79 \mathrm{~m}$ & $4.55 \mathrm{~d}(5.0)$ \\
\hline & $2.02 \mathrm{~m}$ & $2.02 \mathrm{~m}$ & & $2.03 \mathrm{~m}$ & \\
\hline \multirow[t]{2}{*}{15} & $2.26 \mathrm{~m}$ & $2.22 \mathrm{~m}$ & $2.26 \mathrm{~m}$ & $2.27 \mathrm{~m}$ & $2.51 \mathrm{~m}$ \\
\hline & $1.40 \mathrm{~m}$ & $1.68 \mathrm{~m}$ & $2.21 \mathrm{~m}$ & $1.41 \mathrm{~m}$ & $2.22 \mathrm{~m}$ \\
\hline \multirow[t]{2}{*}{16} & $2.21 \mathrm{~m}$ & $2.27 \mathrm{~m}$ & $2.30 \mathrm{~m}$ & $2.45 \mathrm{~m}$ & $2.26 \mathrm{~m}$ \\
\hline & $2.19 \mathrm{~m}$ & & $2.13 \mathrm{~m}$ & $2.16 \mathrm{~m}$ & $2.20 \mathrm{~m}$ \\
\hline 18 & $1.00 \mathrm{~s}$ & $1.02 \mathrm{~s}$ & $1.00 \mathrm{~s}$ & $1.02 \mathrm{~s}$ & $1.00 \mathrm{~s}$ \\
\hline 19 & $1.03 \mathrm{~s}$ & $1.10 \mathrm{~s}$ & $1.04 \mathrm{~s}$ & $1.04 \mathrm{~s}$ & $1.04 \mathrm{~s}$ \\
\hline 20 & $2.82 \mathrm{~m}$ & $2.82 \mathrm{~m}$ & $2.99 \mathrm{~m}$ & $2.97 \mathrm{~m}$ & $3.10 \mathrm{~m}$ \\
\hline 21 & $1.03 \mathrm{~d}(6.8)$ & $1.03 \mathrm{~d}(6.8)$ & $1.04 \mathrm{~d}(7.0)$ & $1.04 \mathrm{~d}(6.8)$ & $1.05 \mathrm{~d}(7.0)$ \\
\hline \multirow[t]{2}{*}{22} & $1.61 \mathrm{~m}$ & $1.61 \mathrm{~m}$ & $1.83 \mathrm{~m}$ & $1.97 \mathrm{~m}$ & $2.04 \mathrm{~m}$ \\
\hline & $1.50 \mathrm{~m}$ & $1.50 \mathrm{~m}$ & $1.37 \mathrm{~m}$ & $1.27 \mathrm{~m}$ & $1.36 \mathrm{~m}$ \\
\hline 23 & 3.73 dd $(10.2,2.0)$ & $3.73 \mathrm{dd}(10.7,1.2)$ & $3.78 \mathrm{dt}(10.5,1.5)$ & $4.46 \mathrm{dd}(10.7,2.0)$ & $4.61 \mathrm{dd}(11.0,2.0)$ \\
\hline 24 & $3.02 \mathrm{~d}(1.2)$ & $3.03 \mathrm{~d}(1.2)$ & $3.07 \mathrm{~d}(1.0)$ & & \\
\hline 26 & $1.20 \mathrm{~s}$ & $1.20 \mathrm{~s}$ & $1.19 \mathrm{~s}$ & $1.28 \mathrm{~s}$ & $1.29 \mathrm{~s}$ \\
\hline 27 & $1.21 \mathrm{~s}$ & $1.21 \mathrm{~s}$ & $1.22 \mathrm{~s}$ & $1.32 \mathrm{~s}$ & $1.33 \mathrm{~s}$ \\
\hline 28 & $1.08 \mathrm{~s}$ & $1.09 \mathrm{~s}$ & $1.08 \mathrm{~s}$ & $1.08 \mathrm{~s}$ & $1.09 \mathrm{~s}$ \\
\hline 29 & $1.03 \mathrm{~s}$ & $1.08 \mathrm{~s}$ & $1.04 \mathrm{~s}$ & $1.03 \mathrm{~s}$ & $1.04 \mathrm{~s}$ \\
\hline 30 & $1.18 \mathrm{~s}$ & $1.02 \mathrm{~s}$ & $1.30 \mathrm{~s}$ & $1.23 \mathrm{~s}$ & $1.34 \mathrm{~s}$ \\
\hline
\end{tabular}


Table $3{ }^{13} \mathrm{C}$ NMR data of compounds $1-5$ and $18-22\left(600 \mathrm{MHz}, \mathrm{MeOH}-d_{4}, \delta_{\mathrm{C}}\right.$ in ppm)

\begin{tabular}{|c|c|c|c|c|c|c|c|c|c|c|}
\hline No. & 1 & 2 & 3 & 4 & 5 & 18 & 19 & 20 & 21 & 22 \\
\hline 1 & 32.1 & 32.0 & 33.5 & 31.9 & 32.1 & 32.2 & 32.5 & 33.0 & 32.3 & 33.0 \\
\hline 2 & 34.8 & 34.7 & 34.6 & 34.7 & 34.8 & 30.8 & 29.9 & 35.0 & 35.2 & 35.0 \\
\hline 3 & 223.7 & 223.3 & 222.8 & 223.5 & 223.8 & 223.6 & 223.2 & 223.5 & 223.7 & 223.7 \\
\hline 4 & 48.3 & 48.3 & 48.3 & 48.2 & 48.3 & 47.9 & 48.1 & 48.0 & 47.9 & 48.0 \\
\hline 5 & 49.8 & 49.8 & 47.5 & 49.6 & 49.7 & 43.9 & 47.9 & 44.2 & 43.9 & 44.2 \\
\hline 6 & 21.2 & 21.1 & 20.5 & 21.2 & 20.7 & 32.7 & 32.2 & 32.6 & 32.7 & 32.6 \\
\hline 7 & 35.5 & 36.1 & 32.4 & 35.5 & 35.5 & 69.7 & 81.8 & 69.0 & 69.6 & 69.0 \\
\hline 8 & 41.8 & 41.8 & 39.2 & 41.8 & 42.0 & 46.9 & 48.8 & 45.9 & 46.9 & 46.5 \\
\hline 9 & 50.7 & 49.9 & 48.4 & 50.3 & 50.7 & 50.8 & 51.1 & 46.4 & 50.8 & 46.0 \\
\hline 10 & 38.3 & 38.4 & 37.0 & 38.3 & 38.3 & 38.5 & 38.7 & 38.1 & 38.5 & 38.3 \\
\hline 11 & 70.5 & 69.8 & 132 & 70.5 & 70.7 & 70.7 & 70.5 & 71.8 & 70.7 & 72.0 \\
\hline 12 & 35.1 & 34.0 & 124.1 & 35.5 & 35.2 & 35.1 & 35.0 & 67.6 & 35.2 & 67.7 \\
\hline 13 & 139.2 & 152.4 & 139.6 & 144.6 & 139.2 & 139.2 & 140.9 & 141.5 & 139.9 & 142.2 \\
\hline 14 & 58.4 & 47.2 & 52.5 & 56.4 & 58.4 & 58.1 & 58.0 & 57.2 & 58.2 & 57.6 \\
\hline 15 & 31.7 & 44.0 & 39.8 & 41.2 & 31.9 & 32.3 & 34.5 & 34.5 & 32.3 & 29.5 \\
\hline 16 & 30.4 & 205.2 & 119.1 & 86.5 & 30.4 & 30.4 & 30.8 & 32.7 & 30.6 & 29.4 \\
\hline 17 & 136.1 & 148.3 & 136 & 135.5 & 137.1 & 137.3 & 136.1 & 144.5 & 136.5 & 143.7 \\
\hline 18 & 24.6 & 23.5 & 23.1 & 24.3 & 24.6 & 14.9 & 24.6 & 15.2 & 14.9 & 15.1 \\
\hline 19 & 26.2 & 26.1 & 25.2 & 26.1 & 26.2 & 26.0 & 26.1 & 26.1 & 26.0 & 25.9 \\
\hline 20 & 33.2 & & 29.0 & 29.2 & 29.8 & 30.0 & 29.9 & 29.7 & 29.9 & 29.7 \\
\hline 21 & 20.2 & & 20.8 & 19.9 & 21.0 & 20.9 & 20.9 & 20.5 & 20.8 & 20.3 \\
\hline 22 & 39.6 & & 40.2 & 39.1 & 42.1 & 42.0 & 42.0 & 42.1 & 40.5 & 40.5 \\
\hline 23 & 150.2 & & 75.5 & 73.7 & 69.8 & 70.5 & 70.5 & 69.2 & 73.1 & 72.5 \\
\hline 24 & 132.8 & & 86.2 & 67.1 & 79.8 & 79.6 & 79.7 & 79.7 & 219.2 & 218.4 \\
\hline 25 & 201.4 & & 72.3 & 60.3 & 79.7 & 74.8 & 74.8 & 74.6 & 77.8 & 77.8 \\
\hline 26 & & & 26.9 & 25.1 & 23.5 & 27.3 & 27.3 & 27.1 & 28.6 & 28.1 \\
\hline 27 & 26.7 & & 24.2 & 20.3 & 21.7 & 26.7 & 26.8 & 26.2 & 27.8 & 27.7 \\
\hline 28 & 30.0 & 30.0 & 29.7 & 30.0 & 30.0 & 29.6 & 29.9 & 29.1 & 29.6 & 29.5 \\
\hline 29 & 20.6 & 20.6 & 19.9 & 20.7 & 20.6 & 20.8 & 20.8 & 20.8 & 20.7 & 20.8 \\
\hline 30 & 23.6 & 23.3 & 23.8 & 25.5 & 23.9 & 24.4 & 26.5 & 25.6 & 24.4 & 26.1 \\
\hline \multirow[t]{2}{*}{ 16-OEt } & & & & 65.6 & & & & & & \\
\hline & & & & 16.5 & & & & & & \\
\hline \multirow[t]{2}{*}{ 23-OAc } & & & & 172.4 & & & & & & \\
\hline & & & & 21.6 & & & & & & \\
\hline \multirow[t]{4}{*}{ 25-OBu } & & & & & 62.3 & & & & & \\
\hline & & & & & 33.9 & & & & & \\
\hline & & & & & 20.7 & & & & & \\
\hline & & & & & 14.5 & & & & & \\
\hline
\end{tabular}

same conditions to prove the stability of the substrate in the control (blank) culture. Similarly, preparative experiments were carried out in $1000 \mathrm{~mL}$ Erlenmeyer flasks with $400 \mathrm{~mL}$ of potato dextrose medium, and the microorganism was pre-cultured under the above culture conditions for $24 \mathrm{~h}$. Then, $1.0 \mathrm{~mL}$ of 11 or 13 (10 mg mL ${ }^{-1}$, in $\left.\mathrm{MeOH}\right)$ was added to each flask. 11 (200 mg) and 13 (200 mg) were transformed by C. elegans AS 3.2028 and $P$. janthinellum AS 3.510, respectively.

The cultures of $\mathbf{1 1}$ were pooled and filtered, and the filtrates were extracted with EtOAc $(3 \times 8 \mathrm{~L})$ to afford the residue. The residue (6 g) was subjected to silica gel CC eluted with $\mathrm{CHCl}_{3}$ $\mathrm{MeOH}$ (from $40: 1$ to $10: 1$ ) to afford five fraction 1-5. Separation of Fr. 5 (101 mg) by preparative $\mathrm{HPLC}\left(\mathrm{MeOH}-\mathrm{H}_{2} \mathrm{O}, 55 \%\right)$ led to the isolation of compounds 18 (24 mg), 19 (16 mg), and 20 (6 mg).

The cultures of $\mathbf{1 3}$ were conducted as the same method as $\mathbf{1 1 .}$ The residue $(1.6 \mathrm{~g})$ was subjected to silica gel CC eluted with $\mathrm{CHCl}_{3}-\mathrm{MeOH}$ (from $50: 1$ to $10: 1$ ) to afford fraction 1-5. Fr. 4 (121 mg) was purified by preparative $\mathrm{HPLC}\left(\mathrm{MeOH}-\mathrm{H}_{2} \mathrm{O}, 50 \%\right)$, yielding compound 21 (30 mg). Fr. 5 (62 mg) was separated by preparative HPLC $\left(\mathrm{MeOH}-\mathrm{H}_{2} \mathrm{O}, 52 \%\right)$ to obtain compound 22 (12 mg).

7 $\alpha$-Hydroxy alisol A (18). Amorphous powder; $[\alpha]_{\mathrm{D}}^{25}-32.8(c$ $0.2, \mathrm{MeOH}) ; \mathrm{UV}(\mathrm{MeOH}) \lambda_{\max }(\log \varepsilon) 202(4.2) \mathrm{nm} ;{ }^{1} \mathrm{H}(600 \mathrm{MHz}$, $\left.\mathrm{MeOH}-d_{4}\right)$ and ${ }^{13} \mathrm{C}$ NMR $\left(150 \mathrm{MHz}, \mathrm{MeOH}-d_{4}\right)$ data, see Tables 2 and 3; HRESIMS $m / z 529.3507[\mathrm{M}+\mathrm{Na}]^{+}$(calcd for $\mathrm{C}_{30} \mathrm{H}_{50} \mathrm{O}_{6} \mathrm{Na}$, 529.3505).

$7 \beta$-Hydroxy alisol A (19). Amorphous powder; $[\alpha]_{\mathrm{D}}^{25}-16.5(c$ 0.1, MeOH); UV (MeOH) $\lambda_{\max }(\log \varepsilon) 201(4.1) \mathrm{nm} ;{ }^{1} \mathrm{H}(600 \mathrm{MHz}$, $\left.\mathrm{MeOH}-d_{4}\right)$ and ${ }^{13} \mathrm{C}$ NMR $\left(150 \mathrm{MHz}, \mathrm{MeOH}-d_{4}\right)$ data, see Tables 2 and 3; HRESIMS $m / z 529.3517[\mathrm{M}+\mathrm{Na}]^{+}$(calcd for $\mathrm{C}_{30} \mathrm{H}_{50} \mathrm{O}_{6} \mathrm{Na}$, 529.3505).

7 $\alpha, 12 \alpha$-Dihydroxy alisol A (20). Amorphous powder; $[\alpha]_{\mathrm{D}}^{25}-121.7$ (c $\left.0.05, \mathrm{MeOH}\right) ; \mathrm{UV}(\mathrm{MeOH}) \lambda_{\max }(\log \varepsilon) 201$ (3.9) nm; ${ }^{1} \mathrm{H}\left(600 \mathrm{MHz}, \mathrm{MeOH}-d_{4}\right)$ and ${ }^{13} \mathrm{C}$ NMR $(150 \mathrm{MHz}$, MeOH- $d_{4}$ ) data, see Tables 2 and 3; HRESIMS $m / z$ 527.3343 [M + $\mathrm{Na}]^{+}$(calcd for $\mathrm{C}_{30} \mathrm{H}_{48} \mathrm{O}_{6} \mathrm{Na}, 527.3349$ ). 
Table 4 The inhibitory activities against HCE-2 of compounds 1-22

\begin{tabular}{llll}
\hline Compound & $\mathrm{IC}_{50}(\mu \mathrm{M})$ & Compound & $\mathrm{IC}_{50}(\mu \mathrm{M})$ \\
\hline $\mathbf{1}$ & $2.67 \pm 0.04$ & $\mathbf{1 3}$ & $35.61 \pm 1.21$ \\
$\mathbf{2}$ & $75.64 \pm 3.86$ & $\mathbf{1 4}$ & $3.78 \pm 0.21$ \\
$\mathbf{3}$ & $7.44 \pm 0.41$ & $\mathbf{1 5}$ & $6.11 \pm 0.46$ \\
$\mathbf{4}$ & $7.38 \pm 0.18$ & $\mathbf{1 6}$ & $4.18 \pm 0.48$ \\
$\mathbf{5}$ & $0.51 \pm 0.09$ & $\mathbf{1 7}$ & $49.43 \pm 1.79$ \\
$\mathbf{6}$ & $9.45 \pm 0.73$ & $\mathbf{1 8}$ & $18.05 \pm 1.53$ \\
$\mathbf{7}$ & $2.99 \pm 0.60$ & $\mathbf{1 9}$ & $7.39 \pm 1.21$ \\
$\mathbf{8}$ & $3.39 \pm 0.81$ & $\mathbf{2 0}$ & $3.73 \pm 0.76$ \\
$\mathbf{9}$ & $2.58 \pm 0.51$ & $\mathbf{2 1}$ & $21.89 \pm 1.34$ \\
$\mathbf{1 0}$ & ${ }^{a}$ & $\mathbf{2 2}$ & $13.74 \pm 0.09$ \\
$\mathbf{1 1}$ & $99.65 \pm 2.81$ & Loperamide & \\
$\mathbf{1 2}$ & $2.66 \pm 0.59$ & & $1.26 \pm 0.03$ \\
${ }^{a}$ No determined. & ${ }^{b}$ Control drug. & & \\
& & &
\end{tabular}

7 $\alpha$-Hydroxy-24-oxo alisol A (21). Amorphous powder; $[\alpha]_{\mathrm{D}}^{25}-16.7\left(c\right.$ 0.1, MeOH); UV (MeOH) $\lambda_{\max }(\log \varepsilon) 200(3.9) \mathrm{nm}$; ${ }^{1} \mathrm{H}\left(600 \mathrm{MHz}, \mathrm{MeOH}-d_{4}\right)$ and ${ }^{13} \mathrm{C} \mathrm{NMR}\left(150 \mathrm{MHz}, \mathrm{MeOH}-d_{4}\right)$ data, see Tables 2 and 3; HRESIMS $m / z$ 545.3457 [M+ Na] $]^{+}$(calcd for $\left.\mathrm{C}_{30} \mathrm{H}_{50} \mathrm{O}_{7} \mathrm{Na}, 545.3454\right)$.

$7 \alpha, \mathbf{1 2} \alpha$-Dihydroxy-24-oxo alisol A (22). Amorphous powder; $[\alpha]_{\mathrm{D}}^{25}-36.5\left(c\right.$ 0.05, MeOH); UV (MeOH) $\lambda_{\max }(\log \varepsilon) 201(3.8) \mathrm{nm}$; ${ }^{1} \mathrm{H}\left(600 \mathrm{MHz}, \mathrm{MeOH}-d_{4}\right)$ and ${ }^{13} \mathrm{C} \mathrm{NMR}\left(150 \mathrm{MHz}, \mathrm{MeOH}-d_{4}\right)$ data, see Tables 2 and 3; HRESIMS $m / z$ 543.3292 $[\mathrm{M}+\mathrm{Na}]^{+}$(calcd for $\mathrm{C}_{30} \mathrm{H}_{48} \mathrm{O}_{7} \mathrm{Na}, 543.3298$ ).

\section{Inhibitory HCE-2 bioassay}

All the isolated and biotransformed compounds were assayed for inhibitory HCE-2 effects as our pervious method.,14 Compounds 1-22 were dissolved in DMSO and diluted to final concentrations of $0.1,1.0,5.0,10.0,20.0,50.0,100.0$, and 200.0 $\mu \mathrm{M}$. All compounds were hydrolyzed by HCE-2 at $37^{\circ} \mathrm{C}$ with the probe substrate 4-benzoyl- $N$-butyl-1,8-naphthalimide (MPN) in a 96-well plate, then the fluorescence signal was detected at $564 \mathrm{~nm}$. The probe substrate groups (without evaluated compounds) were used as control. Loperamide was used as the control drug.

\section{Molecular modeling}

The initial structure of HCE-2 was modeled in terms of the protein structure of human liver carboxylesterase 1 (HCE-1, PDB ID: 1YA4) using the modeller (version 9) program. ${ }^{25}$ The protein structure of HCE-2 was further refined by performing molecular dynamics (MD) simulations using NAMD 2.9 software. ${ }^{26}$ The long-range electrostatic interactions were treated using the PME method. The integration time step is $2 \mathrm{fs}$. The system was first energy minimized for 10000 steps with the protein structure fixed. Subsequently, the system was heated from 0 to $310 \mathrm{~K}$ in $100 \mathrm{ps}$, followed by an equilibration at $310 \mathrm{~K}$ for $100 \mathrm{ps}$. Langevin dynamics and Langevin piston methods were used to maintain the temperature at $310 \mathrm{~K}$ and pressure at $1 \mathrm{bar}$. The production MD simulations were run for $10 \mathrm{~ns}$. The final $10 \mathrm{~ns}$ protein structure was used for docking with AutoDock software. $^{27}$ The ligand parameters were obtained using the
PRODRG Server (http://davapc1.bioch.dundee.ac.uk/cgibin/ prodrg). The Gasteiger charge was calculated for the HCE-2 protein structure. The grid box was sufficiently large to cover the whole protein, and compound 5 was blindly docked into the protein using the Lamarckian generic algorithm. The other default parameters in AutoDock were applied for docking.

\section{Acknowledgements}

This work is supported by the National Natural Science Foundation of China (No. 81503201), Dalian Outstanding Youth Science and Technology Talent (2015J12JH201), Liaoning BaiQianWan Talents Program, and Innovation Team of Dalian Medical University.

\section{Notes and references}

1 Flora of China Committee, Flora of China, Science Press, Beijing, 1992, pp. 140-142.

2 Pharmacopoeia Commission of People's Republic of China, Pharmacopoeia of the People's Republic of China (Part 1), Chinese Medical Science and Technology Press, Beijing, 2010, p. 212.

3 Z. P. Mai, K. Zhou, G. B. Ge, C. Wang, X. K. Huo, P. P. Dong, S. Deng, B. J. Zhang, H. L. Zhang, S. S. Huang and X. C. Ma, J. Nat. Prod., 2015, 78, 2372-2380.

4 T. Murata, Y. Imai, T. Hirata and M. Miyamoto, Chem. Pharm. Bull., 1970, 18, 1347-1353.

5 T. Murata and M. Miyamoto, Chem. Pharm. Bull., 1970, 18, 1354-1361.

6 X. Z. Hong, H. Q. Tang, L. M. Wu and L. D. Li, J. Pharm. Pharmacol., 2006, 58, 1391-1398.

7 W. F. Fong, C. Wang, G. Y. Zhu, C. H. Leung, M. S. Yang and H. Y. Cheung, Phytomedicine, 2007, 14, 160-165.

8 B. Y. Law, M. Wang, D. L. Ma, F. Al-Mousa, F. Michelangeli, S. H. Cheng, M. H. Ng, K. F. Mok, A. Y. Ko, R. Y. Lam, S. K. Chen, F. Che, C. M. Chiu and B. C. P. Ko, Mol. Cancer Ther., 2010, 9, 718-730.

9 H. Matsuda, T. Kageura, I. Toguchida, T. Murakami, A. Kishi and M. Yoshikawa, Bioorg. Med. Chem. Lett., 1999, 9, 30813086.

10 J. H. Lee, O. S. Kwon, H. G. Jin, E. R. Woo, Y. S. Kim and H. P. Kim, Biol. Pharm. Bull., 2012, 35, 1581-1587.

11 M. Kubo, H. Matsuda, N. Tomohiro and M. Yoshikawa, Biol. Pharm. Bull., 1997, 20, 511-516.

12 H. Dan, J. Wu, M. Peng, X. F. Hu, C. W. Song, Z. W. Zhou, S. G. Yu and N. B. Fang, Saudi Med. J., 2011, 32, 701-707.

13 S. S. Wu, G. G. Guo, H. Shi, H. Wang and L. Davia, China J. Tradit. Chin. Med. Pharm., 2007, 22, 475-477.

14 Z. P. Mai, X. L. Xin, N. Zhang, S. S. Huang, C. Wang, L. Chen, Y. Li, X. K. Huo and G. J. Fan, Phytochem. Lett., 2015, 13, 228233.

15 D. F. Yang, R. E. Pearce, X. L. Wang, R. Gaedigk, Y. J. Yvonne Wan and B. F. Yan, Biochem. Pharmacol., 2009, 77, 238-247.

16 K. J. P. Yoon, J. L. Hyatt, C. L. Morton, R. E. Lee, P. M. Potter and M. K. Danks, Mol. Cancer Ther., 2004, 3, 903-909. 
17 M. J. Hatfield and P. M. Potter, Expert Opin. Ther. Pat., 2011, 21, 1159-1171.

18 J. Cang, C. Wang, X. K. Huo, X. G. Tian, C. P. Sun, S. Deng, B. J. Zhang, H. L. Zhang, K. X. Liu and X. C. Ma, Phytochem. Lett., 2017, 19, 83-88.

19 Y. Nakajima, Y. Satoh, M. Katsumata, K. Tsujiyama, Y. Ida and J. Shoji, Phytochemistry, 1994, 36, 119-127.

20 A. C. Zhou, C. F. Zhang and M. Zhang, Chin. J. Nat. Med., 2008, 6, 109-111.

21 G. P. Peng and F. C. Lou, Nat. Prod. Res. Dev., 2011, 13, 1-4. 22 M. Yoshikawa, S. Hatakeyama, N. Tanaka, Y. Fukuda, J. Yamahara and N. Murakami, Chem. Pharm. Bull., 1993, 41, 1948-1954.
23 T. Murata, M. Shinohara, T. Hirata, K. Kamiya, M. Nishikawa and M. Miyamoto, Tetrahedron Lett., 1968, 1, 103-108.

24 X. L. Xin, Y. Wang, G. J. Fan, L. Chen and C. P. Sun, Phytochem. Lett., 2017, 19, 210-214.

25 A. Šali and T. L. Blundell, J. Mol. Biol., 1993, 234, 779-815.

26 J. C. Phillips, R. Braun, W. Wang, J. Gumbart, E. Tajkhorshid, E. Villa, C. Chipot, R. D. Skeel, L. Kale and K. Schulten, J. Comput. Chem., 2005, 26, 1781-1802.

27 G. M. Morris, R. Huey, W. Lindstrom, M. F. Sanner, R. K. Belew, D. S. Goodsell and A. J. Olson, J. Comput. Chem., 2009, 30, 2785-2791. 